JRIM

5,1

50

Received August 2010

Revised October 2010

Accepted January 2011

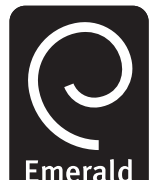

Journal of Research in Interactive Marketing

Vol. 5 No. 1, 2011

pp. $50-70$

(C) Emerald Group Publishing Limited 2040-7122

DOI $10.1108 / 17505931111121525$

\section{The influence of MLM companies and agent attributes on the willingness to undertake multilevel marketing as a career option among youth}

\author{
Joyce Koe Hwee Nga \\ School of Business, Sunway University, Petaling Jaya, Malaysia, and \\ Soo Wai Mun (Nadiah Soo) \\ Taylors Busines School, School of Accountancy and Finance, \\ Taylor's University, Petaling Jaya, Malaysia
}

\begin{abstract}
Purpose - The direct selling industry is experiencing phenomenal growth in Malaysia. The Domestic Trade, Cooperatives and Consumerism Ministry projects that there will be a 20 percent increase in volume of direct sales growth to RM5.5 billion in 2010, RM6.2 billion in 2011 and RM7 billion in 2012. The Direct Selling Act 1993 has been reinforced to accord protection to potential consumers. With the real wages in Malaysia decreasing and increasing unemployment especially among fresh graduates there may be a greater incentive to explore multilevel marketing (MLM) to supplement their income and maintain their desired modern lifestyle. However, the perception of MLM has in the past been tainted by unscrupulous pyramid and Ponzi schemes which aims at quick profits and are not sustainable. This paper aims to investigate the influence of perception of MLM companies and agent attributes on the willingness to undertake MLM as a career among youth.

Design/methodology/approach - The sample of this study comprised 218 students pursuing business and management degrees at a private higher education institution in Klang Valley, Malaysia. Methodologically, this study developed statistically valid and reliable scales for all the constructs of this study namely perception of attributes of MLM companies (general, schemes and service) an agents (general and trust) as well as willingness to undertake MLM as a career option.

Findings - The findings indicate that all MLM company and agent attributes have a significant influence on the willingness to undertake MLM as a career option except MLM schemes. General agent attributes displayed a significant negative influence.

Practical implications - MLM companies need to make their schemes more understandable and transparent to solidify the legitimacy and sustainability as the employer of choice.

Originality/value - The paper shows that MLM remains a viable career option for youth and they need to be equipped with adequate training in personal selling, entrepreneurship and soft skills. MLM companies can tap and nurture this pool of young talent to meet their human resource needs for future growth of this industry in Malaysia.
\end{abstract}

Keywords Multilevel marketing, Young consumers, Personal selling, Direct selling, Malaysia

Paper type Research paper

\section{Background of the study}

The pressures of the competitive modern lifestyle, increase in cost of living, as well as job insecurity are some of the factors that create the need to supplement monthly income. 
Besides, that, the goal of providing for a better quality of retirement, family support, as well as the passion to pursue individual ambition and aspirations also require additional financial resources which may not be achievable under the present mediumand low-income employment. Multilevel marketing (MLM) provides an opportunity at minimum costs and time flexibility to achieve financial independence, if the individual manages to secure a loyal sales base. MLM is a genre of personal selling where products or services are distributed by the agent to the customer through personal contact without the need for a permanent business location (Direct Selling Association of Malaysia, 2010). The Malaysian Ministry of Domestic Trade, Cooperatives and Consumerism reported that as of 31 December 2009, direct selling licenses were granted to 491 companies, of which 350 companies have a MLM plan (MDTCC, 2010). The sales from the direct selling industry in Malaysia were valued at RM 3.7 billion in year 2008 (MDTCC, 2010). However, MLM as a concept has been plagued with its negative association with "get rich quick" pyramid and Ponzi schemes which thrive on securing their revenue mainly from large initial fees upon recruitment. This has led to the violation of trust and raised many questions about legitimacy of MLM as a viable career option.

This paper begins by discussing the underpinning theories surrounding the concept of MLM. The paper also discusses the issues pertaining to the independent variables of this study namely the service, reward schemes, company and agent characteristics, as well as trust on MLM companies. The dependent variable of this study is the willingness to undertake MLM as a career option. There is currently a dearth in studies pertaining to the willingness to take up MLM as a career option in Malaysia. As such, an exploratory quantitative survey was conducted with a sample of 218 undergraduate students pursuing business and management courses at a private higher education institution in Klang Valley, Malaysia, to answer the following questions:

$R Q 1$. What is the influence of the perception of MLM company characteristics (reward schemes, service provided and general company image) on the willingness to take up MLM as a career option?

$R Q 2$. What is the influence of the perception of MLM agent characteristics (trust and general agent attributes) on the willingness to take up MLM as a career option?

RQ3. Do demographic variables (gender, semester of study, race and perception of family income) influence the willingness to take up MLM as a career option?

The conceptual framework of the study is shown in Figure 1.

\section{Multilevel marketing}

In essence, MLM is a combination of transactional and relationship marketing. It operates by stipulating compensation schemes (comprising commissions and bonuses) for products or services sold, as well as recruitment of agents (Bloch, 1996). It is often described as direct selling or network marketing. MLM relies on the selling, entrepreneurial capabilities and personal contacts of their agents, involving minimum upfront investments. In Malaysia, agents of established MLM companies such as Tupperware, Amway and Nu Skin rely on brand appeal to market their product. Legitimate MLM companies derive their revenue mainly via retail sales, incorporate buy back policies and do not mandate purchases of training materials (Koehn, 2001). Figure 2 shows a typical MLM network structure. Direct distributors are stockists/retailers who

\section{The influence of MLM companies}




\section{JRIM}

5,1

52

Figure 1.

Conceptual framework

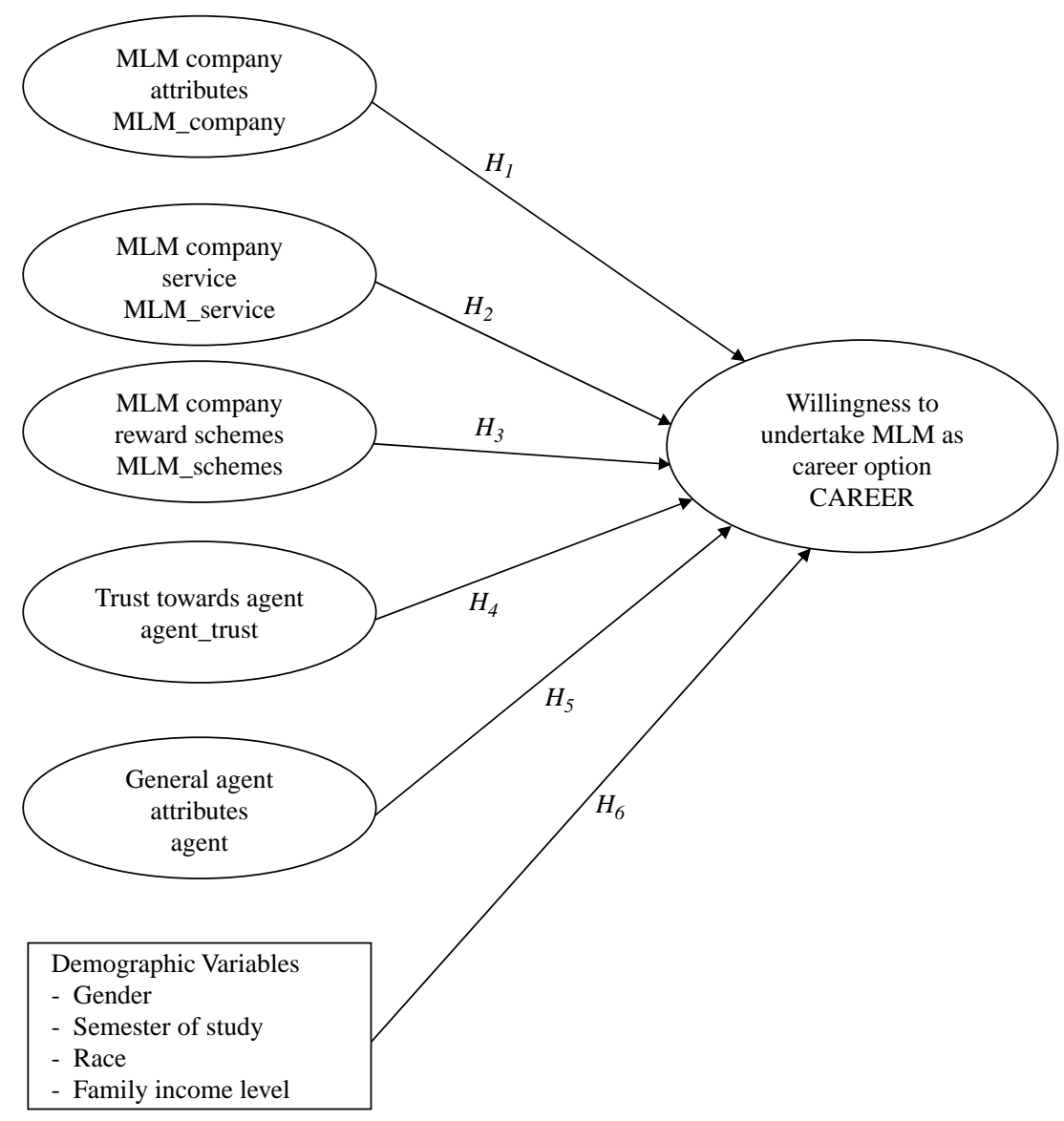

bulk purchase from the direct sales company for subsequent sales to distributors and consumers. Their compensation is derived from sales volume (personal and group) commissions. Distributors pursue "face to face" personal selling without the need for a fixed store front. There is usually a distinction between the retail price to customers and the distributor's price. Distributors are often accorded a discount from the retail price. Active distributors often encourage family, friends and acquaintances to join the network and enjoy the reward of sustained sales volume. MLM companies also provide support in terms of continuous training, motivation courses, as well as rewards and incentives (e.g. overseas trips) if targets are achieved (Mswell and Sargeant, 2001).

\section{MLM versus pyramid schemes}

It is important to differentiate between MLM and pyramid schemes as the latter often make promises of high returns centered upon recruitment rather than retail sales (Koehn, 2001; Vander Nat and Keep, 2002). Pyramid schemes also require large upfront investments or offer dubious products promising miracle cures at exorbitant prices. Pyramid schemes appeal to human greed, fear and exploit trust in social networks. 


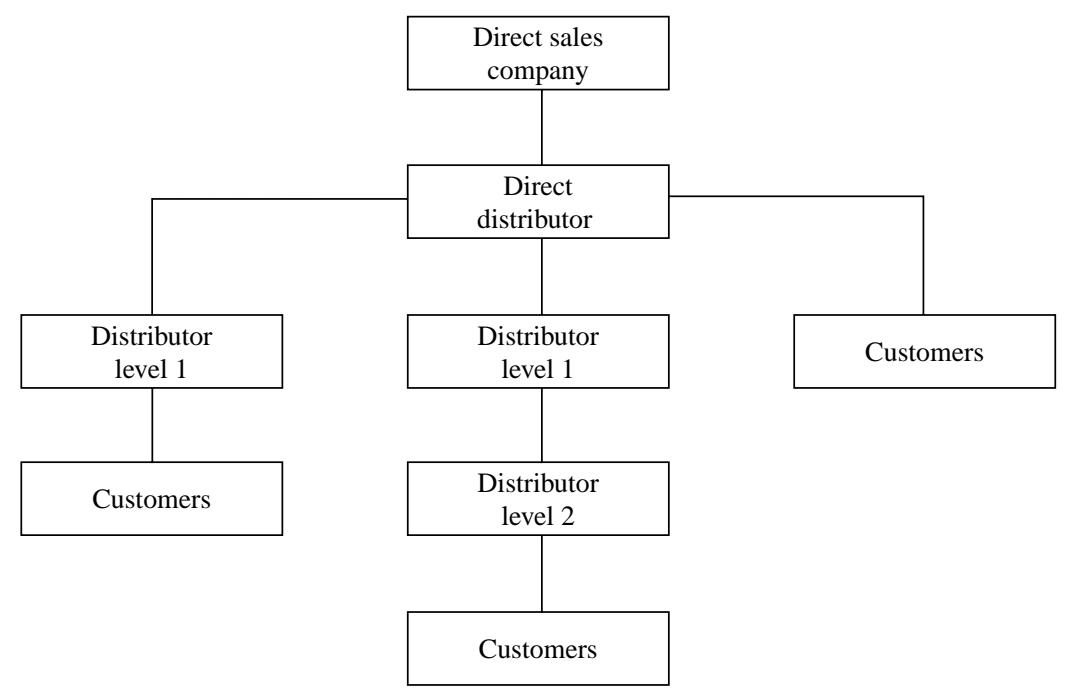

Source: Adapted from the Direct Selling Association of Malaysia (2010)

\section{The influence of MLM companies}

53

Figure 2.

Structure of a typical MLM network plan

As such, pyramid schemes have often been perceived negatively of profiteering from questionable ethics, misrepresentation and leveraging on the numbers game (Kustin and Jones, 1995; Bloch, 1996; Vander Nat and Keep, 2002, Koehn, 2001; Constantin, 2009). Recruitment and selling are often conducted on the pretext of sharing a business that fulfils a lucrative dream opportunity (Grant, 1988).

Another variant of illegal pyramid schemes is the Ponzi scheme. The modus operandi of Ponzi schemes is via promise of extremely superior returns to investors in a short time span by rolling over investments of its members (Wells, 2010). Ponzi schemes do not link investments with commercial activity. Legitimate MLM relies on social networks for direct sales exchanges and recruitment of prospects. Legitimate MLM is also grounded within the concept of personal selling in the context of transactional and relationship marketing. The following sections discuss the abovementioned marketing concepts in greater detail.

\section{Transactional marketing}

Transactional marketing originates from classical management theory. It emphasizes the hallmark "4Ps" of marketing namely price, product, promotion and place which was popularized by Philip Kotler (Chaston and Mangles, 1999; Beverland and Lindgreen, 2002). Transactional marketing is short-term oriented and more suited towards generic products and assumes that consumers are price sensitive. For established companies involved in mass production, branding which provides product identity and assurance substitutes the need for personal relationships (Palmer, 1997).

\section{Relationship marketing}

Relationship marketing relies on trust, personal bonds, communication, shared values, empathy and reciprocity both to establish confidence and to foster lasting mutual exchanges (Sin et al., 2002). In contrast with transactional marketing, relationship marketing 
JRIM

5,1

54

aims at creating an added value proposition by enhancing the customer experience process within the exchange (Grönroos, 2001). Relationship marketing stresses that focus on customer retention rather than just on recruitment may be more profitable (Pottruck, 1987; Harwood and Garry, 2006). Fostering a continuing relationship provides assurances, trust, confidence, lower perceived exchange risk, as well as reduces search costs for the customer. Customer satisfaction is achieved by an active engagement in understanding and meeting their local needs and sealing their loyalty (Ravald and Grönroos, 1996). Consequently, MLM agents are treated as both customers and partners of an integrated sales cum social network. As such, an individual's passion, integrity, empathy, capacity to be a good listener and communicator are critical in relationship marketing (Williams et al., 2009). Relationship marketing also depends on the building of trust through shared values (Palmer, 1997; Constantin, 2009). Thus, relationship marketing is often mobilized to secure meaningful human bonding prevalent in recruitment, establishing long-term customer loyalty and value creation in certain complex niches (Beverland and Lindgreen, 2002). As a result, MLM networks often multiply through word of mouth (Constantin, 2009). In MLM, the customer may not be part of the organization but may be an active a part of the network (Gummersson, 1994).

A dissention on that loyalty programs are part of relationship marketing was advanced by O'Malley and Tynan (2000). They further argue that the tangible outcomes of loyalty do not indicate existence business to consumer $(\mathrm{B} 2 \mathrm{C})$ relationships unless there is evidence of emotional or affective components. Furthermore, they posit that relationship marketing is a conceptually distinct concept from transactional marketing and direct marketing; and that the application of relationship marketing to B2C relationships based on the social exchange theory is more rhetoric than reality. However, Sheth and Parvatiyar (1995) argue that consumers may be motivated to reduce their choices and engage in relationships with the marketer as they perceive the risks to be lower, have a sense of psychological comfort and to safe time in information gathering and processing. Furthermore, social exchange rather than transactional exchange constructs were found to be emphasized more by consumers in B2C relationships (Sorce and Edwards, 2004). Agents of MLM companies are entrepreneurs cum sales representatives. They rely on building social cum sales networks through social exchanges to conduct transactions and service the needs of their customers. As such, elements of relationship marketing are evidenced in MLM.

Zinelsin and Philipson (2007) argue that based on the market mix concept propagated in the 1960s transactional and relationship marketing were not intended to be treated as distinct concepts. Under the marketing mix concept the 4Ps were integrated within other elements such as branding, personal selling, advertising, packaging, display, service, physical handling and fact finding/analysis. Many other authors have advocated extensions to the 4P concept (Gummersson, 1994). MLM combines both transactional and relationship marketing elements with the entrepreneurial skills of its members to conduct exchanges of goods or services and recruitments (Chaston and Mangles, 1999).

\section{Stages versus states theory of relationship marketing}

There are two views on how relationships develop, namely stages and states (Rao and Perry, 2002; Palmer, 2007). Stages theory posits that relationships are predictable and develop in an incremental and sequential nature over time. On the other hand states theory posits that relationships are complex, unpredictable, dynamic and may be enhanced, could deteriorate or remain static over time. 
In relation to MLM, the style of relationships may need to be adapted to different contexts and customers. The MLM agent would then adjust his/her behavior to a platform that conforms to the norms of behavior that enables greater trust to be established. However, whilst shared values are expected to take its course to develop, there is generally no fixed path or correlation between the time taken and quality of relationships established. As such, MLM relationships may be more of a "stages within a state" phenomenon. The degree of complexity of the plan, personal perceptions of the company and ability of the agent to respond to enquiries may influence the development of long-term exchange bonds (Harwood and Garry, 2006). Social intelligence plays an important role in matching the appropriate social style to the situation.

\section{The partnering theory}

In MLM, the direct sales company, agents and customers share a symbiotic partnership to achieve future sales and growth. The partnering theory of relationship marketing suggests that the effectiveness of this is dependent upon the level of trust and commitment between partners and customers (Garbarino and Johnson, 1999). Future repeat purchases will also be dependent on the satisfaction derived from the familiarity and service derived from the sales agents (Fruchter and Sigué, 2005). Thus, MLM companies and agents need to think beyond short-term profitability and invest in establishing relationship commitments as equal partners to foster greater trust and entrepreneurial pursuits in sustaining their value proposition to customers.

\section{Willingness to undertake MLM as a career option}

The sample of this study comprised youth of generation $Y$ who were born between the years 1977 and 1995. This generation is characterized by their technological suaveness, short-term orientation, affinity towards instant gratification, high self-esteem, social image consciousness and willingness to undertake risks (Heaney, 2007; Twenge and Campbell, 2008). Generation Y are challenged with higher costs of basic needs in maintaining the desired modern lifestyle. As such, it is not surprising that college students have been targets of MLM companies according to a paper in The Star, 25 August 2010 entitled "Direct way to money." Many students are also agents or customers of MLM companies. As such, they are aware of performance targets, required attributes and training of MLM agents.

The experience gained through these part-time vocations while at university combined with technical skills acquired through business and management courses (such as marketing, communications, accounting and finance) may open up new avenues of career options. MLM also provides the flexibility in terms of location and time to conduct sales with minimum investment and rewards that commensurate with individual effort. However, there remains a dearth in studies on the willingness of generation $\mathrm{Y}$ to engage MLM as a career option. This study aims to bridge this knowledge gap. Five hypotheses have been developed for this study to investigate the influence of MLM companies and MLM agent characteristics on the willingness to consider MLM as a career option.

To address $R Q 1, H 1-H 3$ have been posited. The rationale behind these hypotheses is provided below:

H1. The perception of general MLM company attributes (MLM_COMPANY) will have an influence on the willingness to take up MLM as a career option (CAREER).

The influence of MLM companies 
JRIM

5,1

56

As discussed above, MLM companies have regrettably borne some of the negative attribution towards pyramid and Ponzi schemes. However, some multinational MLM companies such as Amway have managed to withstand and mitigate these adverse perceptions through corporate commitment towards a culture of excellence built upon shared mission and partnership with its members (Grant, 1988):

H2. The perception of general MLM company service (MLM_SERVICE) will have an influence on the willingness to take up MLM as a career option (CAREER).

MLM services include providing sound technical advice, easy access to distributors, high-quality products and incorporating customer feedback for improvement. Certain companies such as Tupperware provide lifetime warranties for defects such as chipping, warping, cracking and peeling of their products under normal use (Tupperware Brands, 2010). Amway Global has a satisfaction guarantee clause that permits return of certain products for a full refund or replacement (Amway Global, 2010). These assurances instill confidence and demonstrate these companies' commitment towards delivering value to their customers and new recruits:

H3. The perception of general MLM company reward schemes (MLM_SCHEMES) will have an influence on the willingness to take up MLM as a career option (CAREER).

Legitimate MLM schemes will involve low upfront fees, reward retail sales to end consumers, buy back policies and do not mandate purchase of sales and/or training materials (Koehn, 2001; Constantin, 2009).

The reward schemes offered need to be easily understood and profitable to the members who intend to take this up as a career option (Duffy, 2005). The reward proposition needs to be clearly differentiated from competitors. The MLM company also needs to continuously strive to provide innovative product offerings that are attractive to sustain customer attention and loyalty.

MLM offers a viable supplementary income stream for entrepreneurial individual members. Income will mainly be generated from effort to secure sustainable repeat sales of products and services. Organizational distributor support in terms of training, rewards and incentives have an influence on retention in network marketing firms (Mswell and Sargeant, 2001).

To address RQ2, $H 4$ and $H 5$ have been posited. The supporting reasoning is provided below:

H4. The trust towards MLM agents (AGENT_TRUST) will have an influence on the willingness to take up MLM as a career option (CAREER).

One of the hallmarks of MLM is establishing customer loyalty through long-term social bonds. First impressions of the sales advisor/agent has been found to be passively related to the trust established whilst the last impressions impacted satisfaction attained by the customer (Bergeron et al., 2008). To this extent, trust towards the agent is critical in establishing future confidence and willingness to commit to future exchanges and/or commitments (Rao and Perry, 2002). Trust towards the exchange partner has been found to be positively correlated with sales growth, customer retention, return on investment and market share (Sin et al., 2002): 
H5. The perception towards MLM agents attributes (AGENT) will have an influence on the willingness to take up MLM as a career option (CAREER).

MLM relies on the agent attributes such as enthusiasm, empathy, positive attitude, communication, passion and ethical orientation (Williams et al., 2009). In essence, MLM agents need to exhibit positive cooperative motivations and extend in893/terests of clients/customers above self-interest and sales. There has been empirical research linking interaction intensity and mutual disclosure with salesperson performance (Boles et al., 2000). High sales performers have been found to have high self esteem and are more driven by extrinsic rewards (Brashear et al., 1997):

H6. Demographic factors (gender, semester of study and family income level) will have an influence on the willingness to take up MLM as a career option (CAREER).

\section{Methodology}

Sampling design

This study aims at examining whether there are any theoretical links between the constructs of the study illustrated on the conceptual model in Figure 1 and thus adopts a purposive judgmental sampling design (Cavana et al., 2000, p. 263). The scale for all the constructs were developed for this study based on review on extant literature above. The five-point Likert Scale was used with 1 indicating strongly disagree to 5 strongly agree.

\section{Measurement assessment \\ Validity}

The convergent and discriminant validity of the independent and dependent constructs of this study is accessed via exploratory factor analysis (EFA) adopting the principle component analysis (PCA). The Direct Oblimin factor rotation method is used as the factors are expected to be related to each other. Factor loadings of 0.40 and above based on the pattern matrix are considered significant (Hair et al., 2010, p. 117). Constructs with eigenvalues 1 and more are considered valid factors. The Kaiser-Mayer-Olkin (KMO) measure of sample adequacy of above 0.50 and the significance of $\chi^{2}$ of the Bartlett's test of sphericity indicating an anti-identical matrix (Hair et al., 2010, pp. 103-4; Field, 2005, pp. 641-52) are adopted as the test of assumptions for EFA.

\section{Reliability}

The reliability of the six constructs of this study as shown on Figure 1 is assessed using Cronbach's alpha. The threshold of above 0.60 has been adopted for this study in line with Nunnally (1967, cited in Peterson (1994)), Cavana et al. (2000, p. 320), Hair et al. (2010, p. 125).

\section{Data analysis}

The testing of the five hypotheses in the conceptual framework is conducted via the multiple linear regression (MLR) method. The dependent constructs of this study is the willingness to undertake as career option (CAREER). The independent constructs are MLM company characteristics (MLM_COMPANY), MLM company service (MLM_SERVICE), MLM company reward schemes (MLM_SCHEMES), trust towards MLM agent (AGENT_TRUST) and MLM agent general attributes (AGENT).
The influence of MLM companies 
JRIM

5,1

58

Model fit is deemed to be achieved if the $F$-statistic yields a $p$-value of less than 0.05 . The critical value of 0.05 is adopted to access the significance of the $t$-values associated with each of the hypotheses of this study.

For demographic characteristics comprising gender, semester of study and family income level, the independent sample $t$-test and analysis of variance are conducted. The Levene's test of equality of variance is used to test the assumption of whether there is homogeneity of variances. Equal variances in at least one variable if the $F$-statistic yields a $p$-value greater than 0.05 . The significance of respective demographic variables (gender, semester of study and family income level) are determined via the significance $F$-statistic of the test of between subjects effects if the $p$-value is less than 0.05 .

\section{Findings}

Descriptive statistics

The sample comprises 218 students pursuing business and management courses at an established private business school in Klang Valley, Malaysia. The majority of the students are from middle income families (59.6 percent), females (59.2 percent) and were from second year of studies (45.4 percent). Table I shows the descriptive statistics for the independent and dependent constructs of this study.

Respondents of this study also considered MLM as a viable income prospect with a mean of 3.16 as shown in Table II.

\section{Validity}

The test of assumptions for the EFA was satisfied with the KMO measure of sample adequacy of 0.81 and Bartlett's test of sphericity $\chi^{2}$ returning a value of 2,437.76 $(\mathrm{df}=436 ; p$-value $<0.05)$. Table III shows the pattern matrix for independent and dependent constructs of this study. All the constructs have eigenvalues of above 1 indicating that they are valid factors and the cumulative percentage of variance explained by all the constructs is 56.84 percent. Table IV shows that all the constructs are positively correlated to one another except for AGENT and MLM_SCHEME.

\section{Reliability}

The Cronbach's alpha for the independent constructs of the study namely MLM_COMPANY, MLM_SERVICE, MLM_SCHEME, AGENT_TRUST and AGENT are $0.83,0.78,0.62,0.82$ and 0.66 , respectively. As for the dependent construct, CAREER the Cronbach's alpha is 0.85 . Since these figures are above 0.60 they have satisfied the assessment of reliability for exploratory research (Hair et al., 2010, p. 125).

Results of hypotheses testing

The MLR model for the testing of the hypotheses of this study is as follows:

$$
\begin{aligned}
\text { CAREER }= & \alpha+\beta_{1} \text { MLM_COMPANY }+\beta_{2} \text { MLM_SERVICE }+\beta_{3} \text { MLM_SCHEME } \\
& +\beta_{4} \text { AGENT_TRUST }+\beta_{5} \text { AGENT }
\end{aligned}
$$

The significance of model fit has been achieved with an observed $F$-statistic of 14.368 with a $p$-value of less than 0.01 . The adjusted $R^{2}$ is 0.264 indicating a large effect size (Cohen, 1992). Based on Table V, the variance inflation factors are below the suggested threshold of ten indicating acceptable degree of collinearity (Hair et al., 2010, pp. 204-5). 


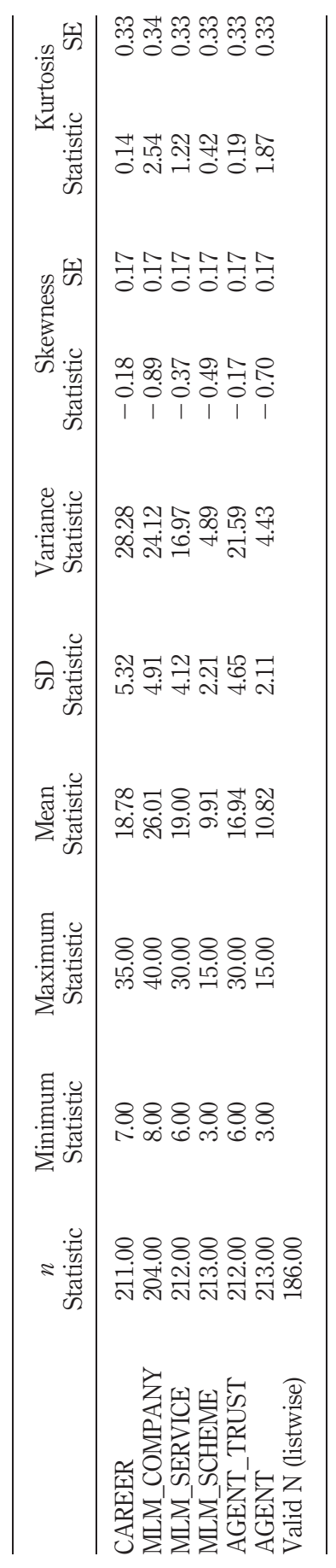

The influence of
MLM companies

59

Table I. Descriptive statistics 


\section{JRIM 5,1}

\section{0}

Table II.

Career option survey items

\begin{tabular}{|c|c|c|c|c|}
\hline & $n$ & Minimum & Maximum & Mean \\
\hline \multirow{8}{*}{$\begin{array}{l}\text { career01 - I would consider MLM as a full-time } \\
\text { career prospect } \\
\text { career02 - I would consider MLM as a reputable } \\
\text { career prospect } \\
\text { career03 - I consider MLM as a good income } \\
\text { prospect } \\
\text { career04 - I consider MLM as a supplementary } \\
\text { income prospect } \\
\text { career05 - A career in MLM would provide me with } \\
\text { a long-term sustainable income } \\
\text { career06 - A career in MLM would provide me with } \\
\text { good social acceptance } \\
\text { career07 - A career in MLM would support my life } \\
\text { style choices }\end{array}$} & 218 & 1 & 5 & 2.23 \\
\hline & 218 & 1 & 5 & 2.51 \\
\hline & 216 & 1 & 5 & 2.88 \\
\hline & 217 & 1 & 5 & 316 \\
\hline & & & & \\
\hline & 217 & 1 & 5 & 2.50 \\
\hline & 216 & 1 & 5 & 2.89 \\
\hline & 217 & 1 & 5 & 2.67 \\
\hline
\end{tabular}

Based on Table IV, the perceptions of the general characteristics of the MLM company exerts a significant positive influence on the willingness to undertake MLM as a career option (CAREER) ( $t$-statistic $=2.438 ; p<0.05), H 1$ is supported. The perception of service of the MLM company also has a significant positive influence on career options $(t$-statistic $=3.496 ; p<0.05), H 2$ is supported. However, $H 3$ failed to be supported as the perception of the MLM scheme did not exert a significant influence on career options $(t$-statistic $=1.489 ; p>0.05)$. The mean score for the three items in the AGENT scale is 10.82 .

In terms of perception of the MLM agent $H 4$ is supported as agent trust exhibited a significant positive relationship with career willingness $(t$-statistic $=2.581 ; p<0.05)$. In addition, $H 5$ is also supported general agent attributes exerts a significant negative relationship with career willingness $(t=-2.411 ; p<0.05)$.

Of all the constructs, MLM_SERVICE is the most important explanatory variable in the model with a $\beta$-value of 0.272 followed by AGENT_TRUST (0.187), MLM_SERVICE (0.183) and AGENT (0.162).

Table VI shows that the $F$-statistic for the Levene's test of equality of variance indicates that the $F$-statistic is $1.219\left(\mathrm{df}_{1}=51, \mathrm{df}_{2}=141\right)$ and the $p$-value is 0.183 . This indicates that there is difference in variances for at least one of the demographic variables. Based on the test of between subjects effects, only family income level has a significant $F$-statistic at the $p$-value of 0.10 . Gender, race and semester of study do not have an influence on the willingness to take up MLM as a career option. As such, $H 6$ is supported only for perception of family income.

\section{Implications of the study \\ Training for MLM agents}

The findings of this study show that MLM agent attributes have a negative and significant influence on the willingness to take up MLM as a career option. The negative relationship suggests that students are put-off by MLM agents who may be overzealous in their selling approach in order to meet their short-term personal sales targets. This finding may also suggest that agents are perceived to lack motivation to serve customers well in the long run. The findings of this study appear to support the USA study conducted 


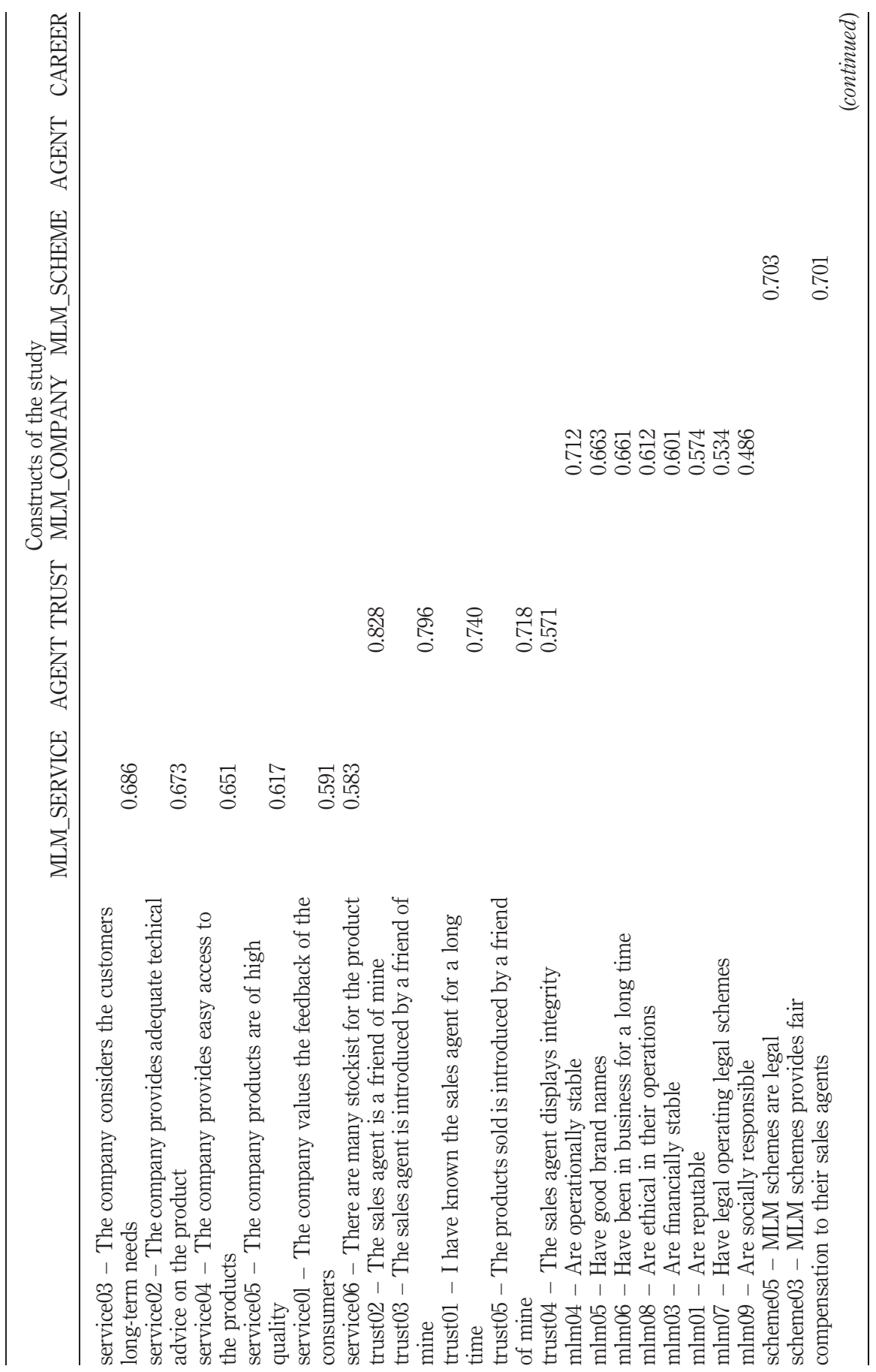

The influence of MLM companies

61

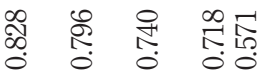

Table III.

Pattern matrix for the EFA 
JRIM

62

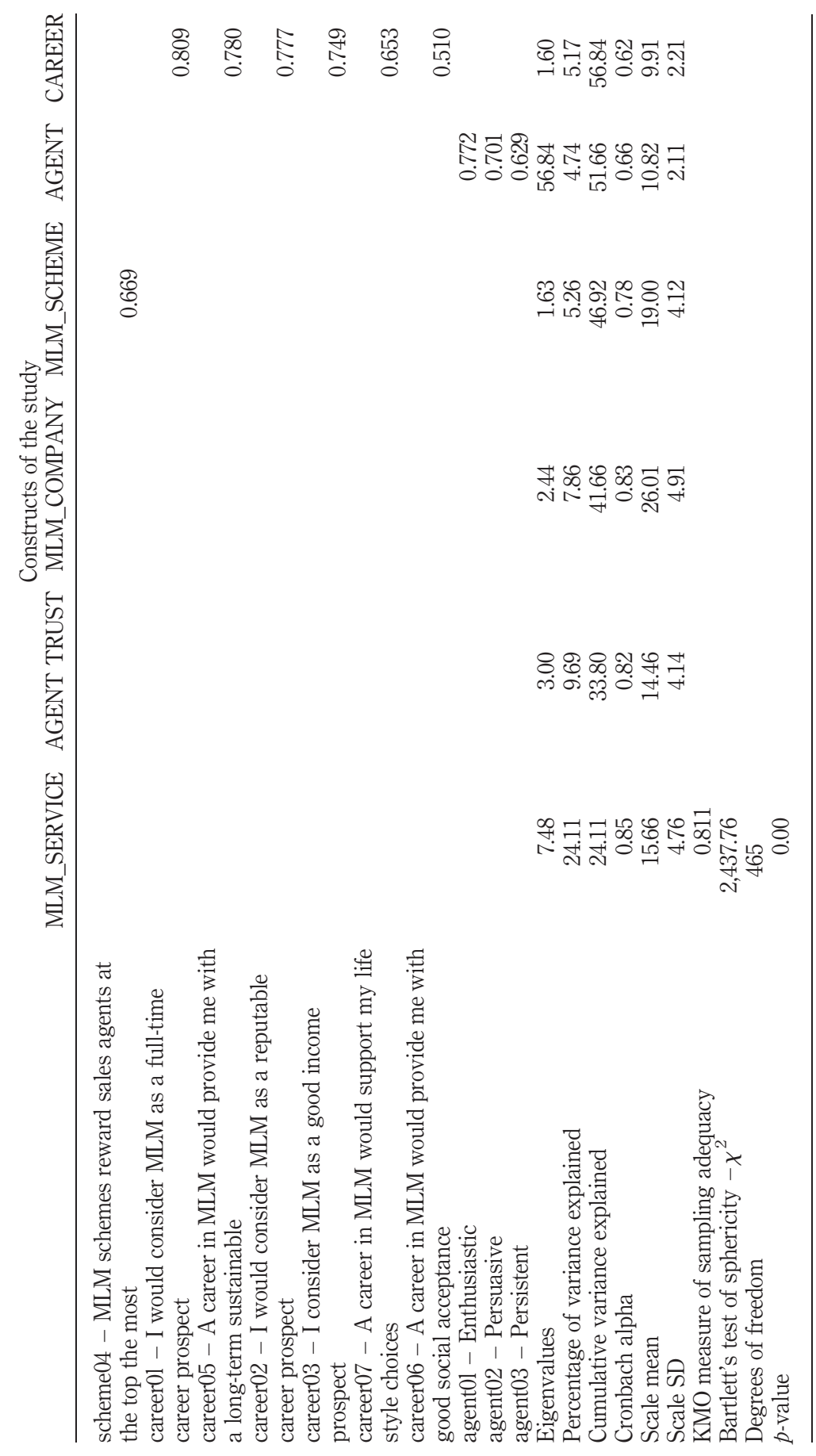




\begin{tabular}{|c|c|c|c|c|c|c|c|}
\hline & CAREER & $\begin{array}{l}\text { AGENT_- }_{\text {TRUST }} \\
\text { TRU }\end{array}$ & $\begin{array}{l}\text { MLM } \\
\text { COMPANY }\end{array}$ & $\begin{array}{l}\text { MLM- } \\
\text { SERV1CE }\end{array}$ & $\begin{array}{l}\text { MLM_ } \\
\text { SCHEME }\end{array}$ & AGENT & MLM companies \\
\hline $\begin{array}{l}\text { CAREER } \\
\text { AGENT }\end{array}$ & 1.00 & & & & & & \\
\hline TRUST & 0.24 & 1.00 & & & & & \\
\hline $\begin{array}{l}\text { MLM } \\
\text { COMPANY }\end{array}$ & 0.33 & 0.12 & 1.00 & & & & 63 \\
\hline MLM_ & & & & & & & \\
\hline $\begin{array}{l}\text { SERVICE } \\
\text { MLM }\end{array}$ & 0.13 & 0.14 & 0.17 & 1.00 & & & Table IV. \\
\hline SCHEME & 0.30 & 0.13 & 0.23 & 0.12 & 1.00 & & Component \\
\hline AGENT & 0.04 & 0.14 & 0.08 & 0.07 & -0.06 & 1.00 & correlation matrix \\
\hline
\end{tabular}

\begin{tabular}{|c|c|c|c|c|c|c|c|}
\hline & \multicolumn{2}{|c|}{$\begin{array}{l}\text { Unstandardized } \\
\text { coefficients }\end{array}$} & \multirow{2}{*}{$\begin{array}{c}\text { Standardized } \\
\text { coefficients } \\
\beta\end{array}$} & \multirow[b]{2}{*}{$t$} & \multirow[b]{2}{*}{ Sig. } & \multicolumn{2}{|c|}{$\begin{array}{c}\text { Collinearity } \\
\text { statistics }\end{array}$} \\
\hline & B & $\mathrm{SE}$ & & & & Tolerance & $\mathrm{V} 1 \mathrm{~F}$ \\
\hline (Constant) & 5.161 & 2.548 & & 2.025 & 0.044 & & \\
\hline MLM_COMPANY & 0.208 & 0.085 & 0.183 & 2.438 & 0.016 & 0.709 & 1.410 \\
\hline MLM_SERVICE & 0.349 & 0.100 & 0.272 & 3.496 & 0.001 & 0.661 & 1.513 \\
\hline MLM_SCHEME & 0.244 & 0.164 & 0.103 & 1.489 & 0.138 & 0.843 & 1.186 \\
\hline AGENT_TRUST & 0.213 & 0.083 & 0.187 & 2.581 & 0.011 & 0.766 & 1.306 \\
\hline AGENT $^{-}$ & 0.407 & 0.169 & 0.162 & 2.411 & 0.017 & 0.890 & 1.124 \\
\hline Adjusted $R^{2}$ & 0.258 & & & & & & \\
\hline$F$-statistic & $13.846^{*}$ & & & & & & \\
\hline
\end{tabular}

Note: ${ }^{*} p$-value $<0.01$

Table V.

Table of coefficients for MLR

\begin{tabular}{|c|c|c|c|c|c|}
\hline Source & Type I sum of squares & $\mathrm{df}$ & Mean square & $F$ & Sig. \\
\hline \multicolumn{6}{|c|}{ Dependent variable: CAREER } \\
\hline Corrected model & 316.981 & 11 & 28.816 & 0.995 & 0.453 \\
\hline Intercept & $66,146.782$ & 1 & $66,146.782$ & $2,284.302$ & 0.000 \\
\hline INCOME_LVL & 143.719 & 2 & 71.859 & 2.482 & 0.086 \\
\hline Semester & 73.586 & 5 & 14.717 & 0.508 & 0.770 \\
\hline RACE & 97.232 & 3 & 32.411 & 1.119 & 0.343 \\
\hline GENDER & 2.444 & 1 & 2.444 & 0.084 & 0.772 \\
\hline Error & $5,241.237$ & 181 & 28.957 & & \\
\hline Total & $71,705.000$ & 193 & & & \\
\hline Corrected total & $5,558.218$ & 192 & & & \\
\hline
\end{tabular}

Notes: $R^{2}=0.057$ (adjusted $R^{2}=0.000$ ); Levene's test of equality of variance: $F=1.219, \mathrm{df}_{1}=51$, $\mathrm{df}_{2}=141, p$-value $=0.183$

Table VI.

Tests of between-subjects effects

by Brisrow et al. (2006) which found that students perceived sales people negatively and were of the opinion that they were not customer-oriented. As such it may appear that MLM agents lack selling skills, confidence and have questionable ethical conduct. This study shows that these characteristics deter students from considering MLM as a career option. 
JRIM

5,1

64
Besides, training on product knowledge, MLM companies need to address and be committed to provide relevant training to their agents in hard and soft skills in personal selling to be more customer-centric and enhance the professional image of the MLM industry. Personal selling courses can be incorporated to improve communication and presentation skills, ability to cope with rejection and facilitate sales deals (Brisrow et al., 2006). It is also critical for MLM companies to instill ethics and professionalism in the conduct of their agents to enhance goodwill among potential customers and in networking activities.

MLM agents need to be encouraged to reflect on their personal selling experiences and share them with their peers to enhance their tacit knowledge. It is important for agents to learn from real-life encounters to see what actually works in the field and how to handle rejections. Personal sharing creates practical awareness, emotional bonding and esprit de corps. Positive emotions have been found to have a contagious motivation effect on personal and group outcomes which in turn has a positive influence on MLM organizational outcomes (Hashim et al., 2008).

As this study has found that MLM is becoming a viable alternative career opportunity, higher educational institutions can complement this by incorporating some component of personal selling skills in the education curriculum for executive courses (e.g. MBA courses). Professional certification courses can be introduced to enhance the credibility of MLM agents.

\section{MLM reward schemes}

The findings of this study reveal that reward schemes did not influence the willingness to undertake MLM as a career option. A possible reason for this is that MLM reward schemes may be difficult to comprehend, as well as may not provide assurance of income and job security. There may also be skepticism in these schemes due to the misconception created by pyramid schemes. Perhaps, MLM companies need to better communicate and educate agents on the viability and sustainability of the earning potential in their reward schemes. MLM companies need to make their performance measures and rewards more transparent and equitable.

\section{Reinforcing positive MLM company and service attributes}

This study found that MLM company and service attributes have significant positive influence on the willingness of youth to pursue MLM as a career option. In MLM, the customer is also a potential independent sales and recruitment agent. As such, being a company of choice entails them to instill greater customer satisfaction (Peck et al., 1998). MLM companies can enhance these attributes by continuously striving to educate, communicate and deliver value to the customer. They need to be committed in reinforcing their brand character and a company culture that nurtures customer loyalty. MLM companies need to continuously uphold high ethical practices and integrity in marketing and in social responsibility. MLM agents need to see their role and view customers as long-term partners.

\section{Entrepreneurship education}

The World Federation of Direct Selling Association reported that 4 million of the 27.5 million Malaysian population (18 percent) is involved in MLM activities as of year 2006 (WFDSA, 2010). This indicates that many Malaysians, including youth, 
have considered MLM as a viable career option. The direct selling business volume is also expected to contribute RM5.5 billion in 2010 which is an increase of 22 percent from 2009 (The Star Online, 27 July 2010). This figure is forecast to increase to RM6.2 billion in The influence of 2011 and RM7 billion in 2012. Besides, this the government has acknowledge the contribution of the industry and also taken the initiative to reinforce The Direct Selling Act 1993 to accord greater protection to consumers. The Malaysian Domestic Trade, Cooperatives and Consumerism Ministry has also indicated its commitment to promote legitimate direct selling endeavors. In addition to stimulating and developing the spirit of entrepreneurship, direct selling may be part of the remedy for the 30,000 graduates that remain unemployed six months post graduation (The New Straits Times, 29 June 2010) and also reduce the current employment rate.

In recent times, the Malaysian Government has reduced subsidies on fuel and sugar (The Star Online, 23 July 2010). This is expected to increase inflation by about 2 percent to 2.5 percent by the end of 2010. Subsidy cuts are expected to continue in the government's efforts to reduce its budget deficit and make Malaysia a more competitive nation. However, this may indirectly cause the cost of living to rise. Real wages in Malaysia have also shown a downtrend over the past ten years (Hunt, 2009). In a culture where filial piety is expected coupled with rising medical costs (Kok, 2009), it becomes even more difficult for the average Malaysian to achieve their financial plans and retirement aspirations (Financial Planning Association of Malaysia, 2010). Legitimate MLM provides a potential income stream for enterprising individuals to supplement their lifestyles. With the increasing cost of living in Malaysia, this study indicates that students are willing and do consider MLM as a potential income supplement. In line with developing more enterprising individuals the education curriculum needs to equip students to be more independent, rational risk takers, soft skills as well as innovative thinking. This is especially important among youth from the lower income families who indicated lower willingness to undertake MLM as a career opportunity as indicated in this study. Entrepreneurship education has been found to positively influence graduates in pursue self-employment as career aspirations (Matlay, 2008). MLM can be one such career option. The education curriculum needs to be both academic and practical with more opportunities for students to discover and craft their life-long learning experience. This can be facilitated via active and problem-based learning approaches (Richardson and Hynes, 2008). To this extent, some universities in Malaysia such as Asia E-University have introduced academic diploma program in network marketing. However, entrepreneurship courses in schools and degree courses are still lacking.

Students need also to be taught basic business skills and how to be "street-wise" so as not to fall susceptible prey for pyramid and Ponzi schemes. Entrepreneurship education also needs to incorporate the importance of ethical conduct and integrity which are critical in building trust in relationship marketing.

\section{Communication skills}

MLM relies on agents being able to foster good relationships with customers and peers. MLM agents need to be able to communicate well in terms of languages as well as have good interpersonal skills. This has often been found lacking by employers in Malaysian fresh graduates (Tneh, 2008; Saari, 2007). As such, there needs to be greater initiatives to develop social intelligence and skills to equip them 
JRIM

5,1

66 to better survive in the marketplace. Students need to be encouraged to participate in an active cooperative learning environment where there is mutual respect and understanding.

The results of the study found that trust towards the MLM agent had a significant positive influence on the willingness to take up MLM as a career. In this respect, the nurturing of emotional intelligence has also been found to be useful in dealing with ambiguity in the entrepreneurship process (Rhee and White, 2007). Emotional intelligence may play an important role for MLM agents in instilling self-confidence, developing trust and deepening tacit communication via social exchanges. Empathy and social awareness may help in identifying the real needs of customers and build valuable long-term relationships.

\section{Opportunities for the MLM industry}

As can be seen from the results and discussion on the implications of this study mentioned above, young people generally are not opposed to consider MLM as a career option. MLM companies could take the opportunity to attract unemployed graduates who generally possess fundamental academic training but need some motivation to embrace entrepreneurship to join the industry. This can be promoted via more transparent reward schemes, relevant training and portrayal of ethical conduct. Thus, the willingness of generation Y to undertake MLM as a career option can be viewed as a viable pool of human resource for the future positive growth of the industry if they are properly nurtured.

\section{Limitations and areas for further research}

This respondent of this study was limited to college students. Further studies can be conducted on other segments of society. MLM may be pursued on a full or part-time basis. Future research may explore what factors influence this choice. Further research is also needed to investigate the characteristics of MLM companies that are considered employers of choice and whether there are difference of preference between local and foreign-based MLMs.

\section{Conclusion}

MLM company, service and agent attributes have been found to influence the willingness to pursue MLM as a career option among youth. In line with the rising cost of living, the implication of this study is that youth do consider MLM as a viable opportunity to supplement income and potential career option. In terms of demographics, only the perception of family income level has an influence on the willingness to undertake MLM as a career option. As such, to better equip youth for their career in MLM, more relevant, active and engaging teaching and learning experiences need to be incorporated in the business education curriculum. Greater emphasis needs to be placed on entrepreneurship education to train students to be more independent and innovative in their outlook. MLM companies need to uphold their positive attributes and commitment towards service and training to remain the employer of choice to reinforce their creditability as a sustainable employer of choice. This study also presents MLM companies with an opportunity to nurture and capitalize on the pool of young, willing and capable young people for the positive future growth of the industry. 


\section{References}

Amway Global (2010), available at: www.amway2u.com/corporate/en_US/amaboutcommit. jsp\#satisfaction (accessed 23 July 2010).

Bergeron, J., Fallu, J. and Roy, J. (2008), "A comparison of the effects of the first impression and last impression in the selling context", Recherche et Applications en Marketing, Vol. 23 No. 2, pp. 19-36.

Beverland, M.B. and Lindgreen, A.L. (2002), "Relationship marketing's appropriateness: a conceptual model and exploratory study", American Marketing Association Conference Proceedings, Vol. 13, pp. 200-6.

Bloch, B. (1996), "Multilevel marketing: what's the catch?", Journal of Consumer Marketing, Vol. 13 No. 4, pp. 18-26.

Boles, J., Brashear, T., Bellenger, D. and Barksdale, H. (2000), "Relationship selling behaviours: antecedents and relationship with performance", Journal of Business \& Industrial Marketing, Vol. 15 Nos 2/3, pp. 141-53.

Brashear, T.G., Bellenger, D.N., Ingram, T. and Barksdale, H.C. (1997), "Salesperson behaviour: antecedents and links to performance”, Journal of Business \& Industrial Marketing, Vol. 12 Nos 3/4, pp. 177-84.

Brisrow, D.N., Gulati, R., Amyx, D. and Slack, J. (2006), “An empirical look at professional selling from a student perspective”, Journal of Education for Business, Vol. 81 No. 5, pp. 242-9.

Cavana, R.Y., Delahaye, B.L. and Sekaran, U. (2000), Applied Business Research: Quantitative and Qualitative Methods, Wiley, New York, NY.

Chaston, I. and Mangles, T. (1999), "A teaching model for integrating the alternative philosophies of transactional, relationship and entrepreneurial marketing", American Marketing Association Conference Proceedings, Vol. 10, pp. 33-9.

Cohen, J. (1992), "Quantitative methods in psychology: a power primer", Psychology Bulletin, Vol. 112 No. 1, pp. 155-9.

Constantin, C. (2009), "Multi-level marketing - a tool of relationship marketing", Bulletin of the Transilvania University of Braşov, Vol. 2 No. 51, pp. 31-6.

Direct Selling Association of Malaysia (2010), "What is direct selling?", available at: www.dsam. org.my/dsam/industry/ (accessed 4 July 2010).

Duffy, D.L. (2005), "Direct selling as the next channel", Journal of Consumer Marketing, Vol. 22 No. 1 , pp. 43-5.

Field, A. (2005), Discovering Statistics Using SPSS, 2nd ed., Sage, London.

Financial Planning Association of Malaysia (2010), "3 Ways to overcome a retirement shortfall”, available at: www.fpam.org.my/fpam/resources/articles-2/general/grow-your-money/2-3ways-to-overcome-a-retirement-funding-shortfall/ (accessed 31 July 2010).

Fruchter, G.E. and Sigué, S.P. (2005), "Transactions vs relationships: what should the company emphasize?", Journal of Service Research, Vol. 8 No. 1, pp. 18-36.

Garbarino, E. and Johnson, M.S. (1999), "The different roles of saltisfaction, trust and commitment in customer relationships", Journal of Marketing, Vol. 63 No. 2, pp. 70-87.

Grant, C. (1988), "Giving ethics the business", Journal of Business Ethics, Vol. 7 No. 7, pp. 489-95.

Grönroos, C. (2001), "The relationship marketing process: communication, interaction, dialogue, value", Journal of Business \& Industrial Marketing, Vol. 19 No. 2, pp. 99-113.

Gummersson, E. (1994), "Making relationship marketing operational", International Journal of Servive Industry Management, Vol. 5 No. 5, pp. 5-19.

The influence of MLM companies 
JRIM 5,1

68
Hair, J.F., Black, W.C., Babin, B.J. and Anderson, R.E. (2010), Multivariate Data Analysis: A Global Perspective, 7th ed., Pearson Prentice-Hall, Upper Saddle River, NJ.

Harwood, T.G. and Garry, T. (2006), "Relationship marketing: why bother?", Handbook of Business Strategy, Vol. 7 No. 1, pp. 107-11.

Hashim, J., Wok, S. and Ghazali, R. (2008), "Organizational behavior associated with emotional contagion among direct selling members", Direct Selling: An International Journal, Vol. 2 No. 3, pp. 144-58.

Heaney, J. (2007), “Generation X and Y's internet banking usage in Australia”, Journal of Financial Services Marketing, Vol. 11 No. 3, pp. 196-210.

Hunt, L. (2009), "Singnificant drop in real wages in Malaysia", The Star Online, 15 January, available at: http://biz.thestar.com.my/services/printerfriendly.asp?file=/2009/1/15/ business/3022966.asp\&sec=business (accessed 31 July 2010).

Koehn, D. (2001), "Ethical issues connected with muti-level marketing schemes", Journal of Business Ethics, Vol. 29 Nos 1/2, pp. 153-60.

Kok, C. (2009), "Rising pressure of healthcare costs", The Star Online, 14 March, available at: http://biz.thestar.com.my/news/story.asp?file=/2009/3/14/business/ $3456038 \&$ sec $=$ business (accessed 31 July 2010).

Kustin, R.A. and Jones, R.A. (1995), "Research note: a study of direct selling perceptions in Australia”, International Marketing Review, Vol. 12 No. 6, pp. 60-7.

Matlay, H. (2008), "The impact of entrepreneurship education on entrepreneurial outcomes", Journal of Small Bisiness and Enterprise Development, Vol. 15 No. 2, pp. 382-96.

MDTCC (2010), available at: www.kpdnkk.gov.my/index.php?option=com_content\& task $=$ view\&id $=453 \& I t e m i d=419$ (accessed 28 February 2011$)$.

Mswell, P. and Sargeant, A. (2001), "Modeling distributor retention in network marketing organizations", Marketing Intelligence \& Planning, Vol. 19 No. 7, pp. 507-14.

O'Malley, L. and Tynan, C. (2000), "Relationship marketing in consumer markets: rhetoric or reality?”, European Journal of Marketing, Vol. 34 No. 7, pp. 797-815.

Palmer, A. (1997), "Defining relationship marketing: an international perspective", Management Decision, Vol. 35 No. 4, pp. 319-21.

Palmer, R. (2007), "The transactional-relational continuum: conceptually elegant but empirically denied”, Journal of Business \& Industrial Marketing, Vol. 22 No. 7, pp. 439-51.

Peck, H., Payne, A., Christopher, M. and Clark, M. (1998), Relationship Marketing: Strategy and Implementation, Text and Cases, Butterworth-Heinemann, Burlington, MA.

Peterson, R.A. (1994), “A meta-analysis of Cronbach's coefficient alpha”, Journal of Consumer Research, Vol. 21 No. 2, pp. 381-91.

Pottruck, D.S. (1987), "Building company loyalty and retention through direct marketing", The Journal of Services Marketing, Vol. 1 No. 2, pp. 53-8.

Rao, S. and Perry, C. (2002), "Thinking about relationship marketing: where are we now?", Journal of Business \& Industrial Marketing, Vol. 17 No. 7, pp. 598-614.

Ravald, A. and Grönroos, C. (1996), “The value concept and relationship marketing”, European Journal of Marketing, Vol. 30 No. 2, pp. 19-30.

Rhee, K.S. and White, R.J. (2007), “The emotional intelligence of entrepreneurs”, Journal of Small Business and Entrepreneurship, Vol. 20 No. 4, pp. 409-26.

Richardson, I. and Hynes, B. (2008), "Entrepreneurship education: towards an industry sector approach”, Education \& Training, Vol. 50 No. 3, pp. 188-98. 
Saari, N.H. (2007), "Unemployed graduates: how can we address this situation", Institut Kefahaman Islam Malaysia, available at: www.ikim.gov.my/v5/index.php?lg=1\& opt $=$ com_article\&grp $=2 \& \mathrm{sec}=\& k e y=1482 \& \mathrm{cmd}=$ resetall (accessed 31 July 2010).

Sheth, J.N. and Parvatiyar, A. (1995), "Relationship marketing in consumer markets: antecedents and consequences", Academy of Marketing Science Journal, Vol. 23 No. 4, pp. 255-72.

Sin, L.Y.M., Tse, A.C.B., Yau, O.H.M., Lee, J.S.Y. and Chow, R. (2002), "The effect of relationship marketing orientation on business performance in a service oriented economy", Journal of Services Marketing, Vol. 16 No. 7, pp. 656-67.

Sorce, P. and Edwards, K. (2004), "Defining business-to-consumer relationships: the consumer's perspective", Database Marketing \& Customer Strategy Managements, Vol. 11 No. 3, pp. 255-67.

Tneh, C.E. (2008), "Education, employment and the economy", Sun2Surf, available at: www. sun2surf.com/article.cfm?id=25659 (accessed 31 July 2010).

Tupperware Brands (2010), available at: www.tupperware.com.sg/quality_assurance_ warranty_main.php (accessed 23 July 2010).

Twenge, J.M. and Campbell, S.M. (2008), "Generational differences in psychological traits and their impact on the workplace", Journal of Managerial Psychology, Vol. 23 No. 8, pp. 862-77.

Vander Nat, P.J. and Keep, W.W. (2002), "Marketing fraud: an approach for differentiating multi-level marketing from pyramid schemes", Journal of Public Policy \& Marketing, Vol. 21 No. 1, pp. 139-51.

WFDSA (2010), "International statistics", World Federation of Direct Selling Agents, available at: www.wfdsa.org/statistics/index.cfm? $\mathrm{fa}=$ display_stats\&number $=1$ (accessed 28 October 2010).

Wells, J.T. (2010), "Ponzis and pyramids", The CPA Journal, Vol. 80 No. 2, pp. 6-10.

Williams, J.D., Everett, R. and Rogol, E. (2009), "Will the human factors of relationship selling survive the twenty first century?", International Journal of Commerce \& Management, Vol. 19 No. 2, pp. 158-75.

Zinelsin, M. and Philipson, S. (2007), "Kotler and Borden are not dead: myth of relationship marketing and truth about the 4Ps", Journal of Consumer Marketing, Vol. 24 No. 4, pp. 229-41.

\section{About the authors}

Joyce Koe Hwee Nga has been attached with Sunway School of Business since November 2009 as a Senior Lecturer. Prior to that, she was as a lecturer at Taylor's Business School since 2001. Prior to this, she has worked in as an Auditor for KPMG, Malaysia as well as Financial Controller for a range of companies in the hospitality industry in Malaysia. She has taught subjects such as corporate financial analysis, corporate finance, financial and corporate reporting, personal finance and international corporate banking management. Her areas of interest are in corporate social responsibility, corporate governance, leadership, strategic management, personal finance, environmental accounting and environmental sustainability. She has a Doctorate in business administration from the University of Newcastle, Australia. The title of her dissertation is "The influence of moral intelligence, social intelligence and demographic factors on corporate social responsibility orientations." She has also presented papers in conferences both locally and internationally. She has an MBA from Charles Stuart University Australia and Bachelor of Economics from University of Adelaide. She is also a Certified Practising Accountant (CPA) with CPA Australia and Chartered Accountant with the Malaysian Institute of Accountants. Joyce Koe Hwee Nga is the corresponding author and can be contacted at: joycen@sunway.edu.my 


\section{JRIM}

5,1

70

Soo Wai Mun (Nadiah Soo) holds a Bachelor of Commerce in accounting, finance and systems, from University of New South Wales, Australia, and a Master of Business Administration (Nanyang Fellows), Nanyang Technological University, Singapore. She was conferred the Dean's Outstanding Achievement Award in the Masters programme. She is currently pursuing her $\mathrm{PhD}$ studies. Nadiah Soo, who is a CPA (CPA Australia) and Chartered Accountant (Malaysian Institute of Accountants), has extensive work experience. She started her career as an auditor, and has since held senior managerial positions in multinational and public listed companies from various industries. She is currently teaching at Taylors University College, Malaysia. She is also active in charity work, and is appointed as the company secretary and financial adviser (voluntary) to a charity organization, which provides financial assistance and counseling services to orphans and "special" children, single mothers and other underprivileged.

To purchase reprints of this article please e-mail: reprints@emeraldinsight.com Or visit our web site for further details: www.emeraldinsight.com/reprints 